\title{
THE NATURAL DEVELOPMENT OF THE WADDEN SEA AFTER THE ENCLOSURE OF THE ZUIDER SEA
}

\author{
C.F.W.Rietveld \\ Engineer, Zuiderzee Works, \\ Sweelinckplein 14, The Hague, The Netherlands
}

\section{ABSTRACT}

The Wadden Sea and Zuider Sea used to form an internal sea which was parated from the North Sea by a chain of islands. In 1932 the Zuider Sea enclosed by a dam $32 \mathrm{~km}$ in length. Owing to this, the Wadden Sea experienc changes in the normal tidal movement, the storm-surge levels and the confi guration of the bed. This article discusses the movement of water and sand the Wadden Sea and its natural development since the enclosure of the Zuid

\section{INTRODUCTION}

The formation of the Wadden Sea and Zuider Sea commenced about the be ginning of the Christian era when the sea broke through the coastal barrie as a result of a rising sea level. The peat and clay areas lying behind tr. coastal barrier where either drowned or eroded away. In this way an interr sea was created, surrounded by a low-lying clay and peat area and bounded the sea side by an intermittent line of coastal dunes. Some tidal inlets n have appeared where the coast was already broken by the mouths of rivers.

As the area of the internal sea increased, the capacity of the tidal lets also increased. This caused increased erosion and so the process was celerated. In the course of the Middle Ages the inhabitants began to stabj lise the coast-line by means of dykes. In this way a dynamic equilibrium established between the rise in sea level and the configuration of the bec the internal sea. The transport of water and sand takes place chiefly in $\varepsilon$ system of channels which branch out stronglylandwards of the tidal inlets. Between these channels lie flats and banks called the Wadden. The height c the Wadden is determined among other factors by the transport of material the sea and the level of high-water. At high-water the Wadden-flats are cc ed by water and some of the suspended material which has been brought in $\varepsilon$ to the bottom. As the water ebbs, not all the material which has settled c is carried back again, so the flats are gradually increasing in level. Thy increase slows down as the level of the Wadden approaches high-water leve] If the sea-level were to remain constant and the amount of material brougk in were sufficient, new land would be created. Vegetation would take root the Wadden would come to lie above high-water level. The reservoir capacit of the sea would become smaller, resulting in a decrease in the size of th channels. However, if the sea-level is continually rising, the level of th Wadden will show a certain delay in response which is dependant on the que tity of material available and the rate of rise in sea-level.

If the increase in sea-level shows fluctuations, an alternate accretj and erosion of the Wadden can occur. By "increase in sealevel" is meant th relative increase in sea-level, consisting of the absolute movement of the sea-level and the movement of the land, which may be susceptible to tector movement of the earth's crust and to consolidation of the sediments.

The geological structure of the Wadden area can be broadly described follows. Westwards of the Vlie Inlet, boulder clay has often been found at depth varying from a few meters to about $20 \mathrm{~m}$ under N.A.P. (Dutch Ordnance Level = mean sea leveld. Boulder clay at depths of less than $20 \mathrm{~m}$ under $\mathrm{N}$ means that this area was an island during the Riss-Würm interglacial. In 1 


\section{COASTAL ENGINEERING}
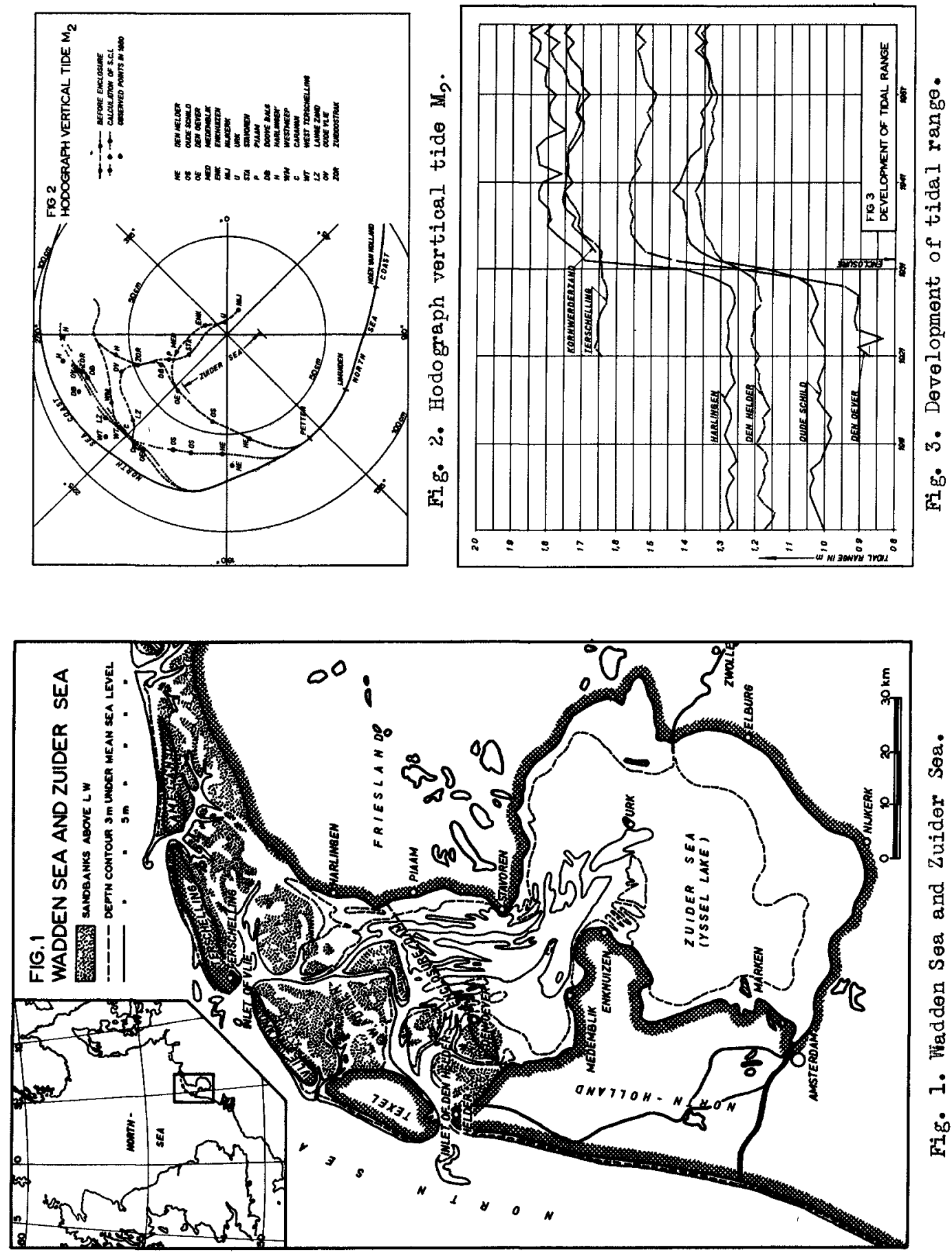


\section{THE NATURAL DEVELOPMENT OF THE WADDEN SEA AFTER THE ENCLOSURE OF THE ZUIDER SEA}

case, marine Eem deposits are not present. During the Würm glacial, lowterrace sand was deposited on the boulder-clay. At the beginning of the ho. locene, about 10.000 years ago, a peat layer was formed on this sand. This peat layer is referred to as "peat at greater depth". On top of the peat as early holocene Wadden deposits and old marine clay ( $5.000-2.000$ B.C.). A1 present the old marine clay extends to $2-2,5 \mathrm{~m}$ under NAP and in places it has a very low chalk content, indicating that this marine clay has at some time lain above high-water. On the old marine clay, the great Dutch peat I: er was formed. In the Wadden Sea this layer has now an average thickness 0 . about $1 \mathrm{~m}$. About at the beginning of our era, erosion of the peat layer st. ed. The great 1088 of land took place in the 13 th and 14 th centuries. Perh this was assisted by the digging of canals and the excavation of peat. On parts of the peat layer which were left, new marine clay or new marine san was deposited, a process which is still taking place.

Thus after the wïrm glacial there were two periods with peat formatio: Then the relative rise in sea-level was retarded or even changed into a tel porary fall, so that the Wadden had the capacity for accretion, using the $m$. terial available.

From about the lst century onwards, the Wadden, which had previously creted by peat formation, were flooded and largely eroded away as a result the relative rise in sea-level.

In this way the Zuider Sea was formed. It was surrounded by land whic was protected by dykes, but which suffered from repeated flooding. During storms, the North Sea water surged through the inlets and high water level could occur as a result of the local wind effect on this shallow sea. Brea in the dykes were common and raising the level of the dykes was very expen as a result of the very long coast-line.

After the storm surge disaster of 1916, the plans for the reclamation a part of the Zuider Sea became definite and an integral part of these pla was the enclosure of the Zuider Sea. The enclosure would prevent high wate levels in the Zuider Sea and reduce the coast-line from a length of c. 250 to $30 \mathrm{~km}$. The remaining part of the internal sea, the Wadden Sea, would re in open connection with the North Sea. Work on the enclosing dam began in and in May 1932 the last gap was closed. The area of the internal sea was by reduced from c. $5200 \mathrm{~km}^{2}$ to $1500 \mathrm{~km}^{2}$. The movement of water in the rema part would experience important alterations, chief of which would be that storm surge levels along the coast would be changed. Because of this, a co mission was set up whose task was to determine how much the enclosure woul raise storm surge levels along the coast outside the enclosing dam abovew would have previously occurred (State Commission Lorentz 1918 - 1926). Thi commission, hereafter referred to as S.C.I., published a comprehensive rep on the changes which would occur in the normal tidal movement and in the $s$ surge levels in the Wadden Sea after enclosure of the Zuider Sea.

As a result of the changes in the movement of water, the topography $c$ the Wadden Sea would experience alterations.

In the paragraphs which follow, the normal tidal movement, the storm surges and the topography of the bed will be described. 


\section{COASTAL ENGINEERING}

\section{II.NORMAL TIDAL MOVEMENT.}

In the Wadden Sea and the former Zuider Sea (now the IJssel lake) tid effects are chiefly dependent on the diurnal lunar tide $M_{2}$. The amplitude the tide is not everywhere the same. See fig 2, in which the amplitude and phase of the $M_{2}$ tide are represented graphically.

Before calculating the increase in storm surge levels due to enclosur of the Zuider Sea, it was first necessary to compute the influence of the enclosure on normal tidal movement.

For this purpose the Wadden Sea and Zuider Sea were schematically represented as a network of flowing channels, separated by flats and banks, which were considered to provide storage capacity.

As tide, the sinusoidal diurnal lunar tide $M_{2}$ was considered. The cal culation was made following the single harmonic method with linear frictio In comparison with the tidal flow, fresh water flow could be neglected.

The boundary conditions were the vertical tide in the North Sea which would not be influenced by the enclosure, and the condition of zero flow a the ends of dead-end channels.

The result of the calculations for the vertical tide in a number of points is shown in fig 2. The amplitude of the vertical tide would increas landwards and in the region of the enclosing dam it would even be doubled places. The capacity of the inlets would increase considerably. The latter be clarified schematically as follows.

Without friction a standing wave would occur with a node at a $1 / 4$ wav length $\lambda$ from the closed end and an antinode at $1 / 2 \lambda$. The "length" of the internal sea is reduced from $0,6 \lambda$ to $0,2 \lambda$ by the enclosure of the zuider $s$ This causes the flow in the inlets to increase. If friction is taken into count, the ratio of the amplitudes of the vertical tidal movement and the at the open end of a uniform channel can, for a sinusoidal tide, be descri by:

in which

$$
\frac{a_{s}^{2}}{a_{h}^{2}}=\frac{4 \pi^{2} b^{2} u^{2}}{4 \pi^{2}+r^{2} \lambda^{2}} \cdot \frac{e^{2 r l}+e^{-2 r l}-2 \cos \frac{4 \pi l}{\lambda}}{e^{2 r l}+e^{-2 r l}+2 \cos \frac{4 \pi l}{\lambda}}
$$

$a_{s}=$ amplitude of the flow

$a_{h}="$ " vertical tide

$u=$ velocity of propogation of the tide

$\lambda=$ wave-length of the tidal wave

$r=$ damping factor resulting from linear friction

$l=$ length of the channel

$b=$ width " "

The first factor in (I) is independent of the length of the canal. The sec factor is a damped oscillation about the value 1 . In the interval between $l=1 / 2 \lambda$ and $l=1 / 4 \lambda$ the value increases with decreasing $l$. Between $l=$ $1 / 4 \lambda$ and $l=0$ the reverse is true. The "lengths" of the Wadden Sea and $Z_{1}$ der sea are respectively $0,2 \lambda$ and $0,4 \lambda$. By the enclorues of the zuider 


\section{THE NATURAL DEVELOPMENT OF THE WADDEN SEA AFTER THE ENCLOSURE OF THE ZUIDER SEA}

Sea the length is reduced from $0,6 \lambda$ to $0,2 \lambda$. Hereby, the ratio $a_{s}^{2} / a_{h}^{2}$ increases.

From the comprehensive tidal calculation it appeared that the increase was so great that it was feared that the tidal inlets would come into a dar gerous situation. This was one of the considerations which led to the enclosing dam being constructed somewhat to the north of where it was originally designed. By this means the danger to the inlets could to some extent be reduced. The length of the Wadden Sea then comes further under the $1 / 4 \lambda$ so that the ratio $a_{s} / a_{h}$ becomes smaller.

The increase in the capacity of the Inlet of Den Helder was reduced fu $30 \%$ to about $25 \%$ in this way.

During and after the enclosure, the development of the tidal movement was carefully observed. The results of the calculations of the S.C.I. apper ed to be in very good agreement with the actual development. In fig 2 the ual vertical $M_{2}$ tide has been drawn for several observation stations.

The adaptation of the tide to the new situation in some parts of the Wadden Sea took place more quickly than in others. This is partially depen on the adaptation of the channel system. As an illustration, fig 3 shows $t$ tidal range before, during, and after enclosure for a number of observatio stations.

In this figure can also be seen the influence of the variation in the inclination of the moon's orbit to the equator. The period of the variatio is 18 2/3 years. Maxima occur in 1922, 1941 and 1960 and the influence on tidal range amounts to $11 / 2-2 \%$.

Correction of the observations since 1933 results in a tidal range wh decreases for Den Oever and Oude Schild, increases for Harlingen and Tersc ling and is almost unchanged for Den Helder and Kornwerderzand. This will referred to in chapter IV.

The regular flow measurements have also largely confirmed the results the tidal calculations.

Another important consequence of the enclosure was the formation of a watershed between the two main inlets of Den Helder and The vile.

With an open Zuider Sea, the tidal streams coming from these inlets w directed towards the Zuider Sea. Since the enclosure, the streams meet eac other in a region near Harlingen, and a watershed has been formed. Because shoaling usually takes place at a watershed, it was important to know whet and, if so, where, there was a chance of shoaling which could be a hindrar to navigation. The tidal calculation gave useful information about this tc The position of the watershed is very much dependent upon the slowly deve] ing system of channels. The situation in this area has still not come to $r$ and the development is regularly surveyed by means of water-level recorder soundings and flow measurements.

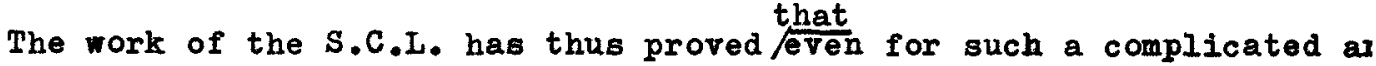
as the Wadden Sea and Zuider Sea tidal calculations can be performed with success. 


\section{COASTAL ENGINEERING}

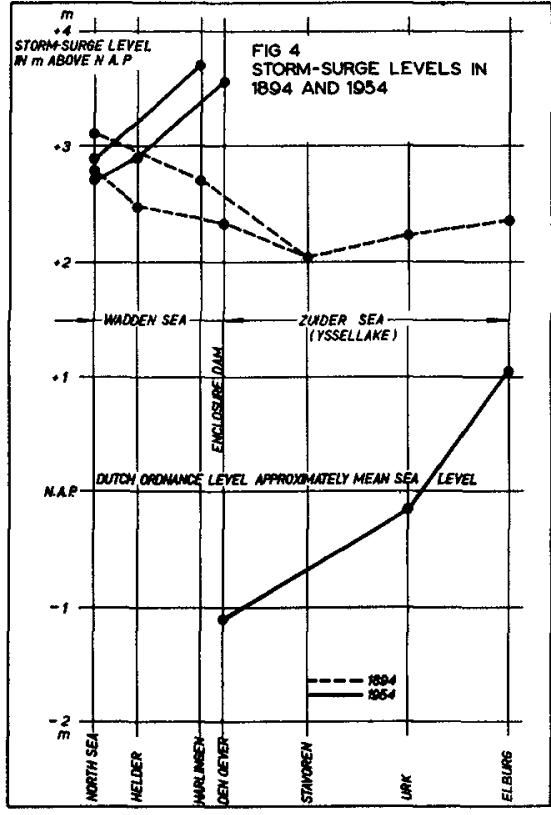

Fig. 4. Storm-surge levels in 1894 and 1954,

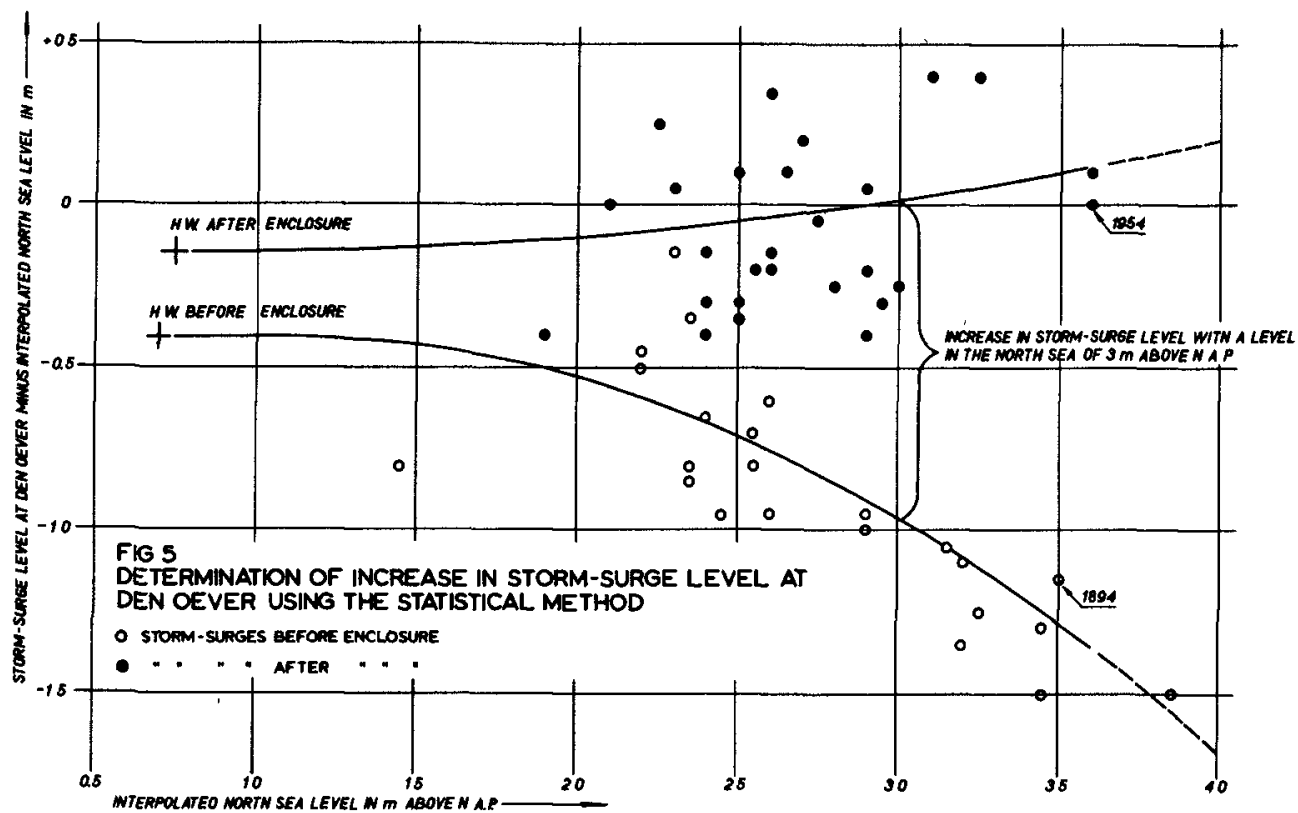

Fig. 5. Determination of increase in storm-surge level at Den Oever using the statistical mothod. 


\section{THE NATURAL DEVELOPMENT OF THE WADDEN SEA AFTER THE ENCLOSURE OF THE ZUIDER SEA}

\section{THE STORM SURGES}

Northwesterly gales increase the water levels along the Dutch coast. A a result of the difference in head and the action of the wind, water flows through the inlets into the Wadden Sea and formerly also into the Zuider Ses If the storm lasts for long enough, a state of equilibrium is reached betwe the force of the wind and the slope of the water surface. If the state of equilibrium is not reached, the maximum water level is not only dependent ol the le-force but also on the degree to which the basins behind the inlets 1 filled. The area of the Wadden Sea and Zuider Sea together was so big relat: to the capacity of the tidal inlets, that even prolonged storms usually fai: to produce complete filling right up to the equilibrium condition. In this the zuider Sea helped to reduce the nighest water levels in the Wadden Sea.

After the enclosure the area was reduced from 5200 to $1500 \mathrm{~km}^{2}$ and the capacity of the inlets is sufficient to cause complete filling of the Wadde Sea if the storm is prolonged. This can be shown by means of fig 4 in which the storm surge levels in the Wadden Sea (and Zuider Sea) are represented $f$ the storms of 1894 and 1954, which were similar. It is clear from the slope the lines that the situation in 1894 was still far from equilibrium. In 195 equilibrium was almost attained. As illustration, several water levels in $t$ IJssel Lake have been drawn in for 1954 to demonstrate the influence of enclosure in lowering the storm surge levels in the IJssel Lake (former Zuide Sea).

From fig 4 it also appears that the levels at Den Helder and Den Oever in 1954 were respectively 0,4 and $1,1 \mathrm{~m}$ higher than in 1894.

The task of the S.C.I. was now to predict how much the known storm sur levels would be raised as a result of the enclosure. It calculated the rise to be expected by various methods. In all cases the observations made of pr vious storms were used. There was no question of extrapolation of frequenci of storm surges because the aim of the enquiry concerned only the rise in known storm surge levels. The sea defences could then be raised so that the same degree of safety against breaching would exist as before the enclosure The height required for the enclosing dam could also be determined from the enquiry. At the time of the S.C.I. the heights of dykes were not determined by using frequencies, but were based on the highest known storm surge level at that point.

The storm of 1894 was taken as the design condition, as it caused the greatest flow from Wadden Sea into Zuider Sea. For this storm very extensiv stationary calculations were made, again using a Wadden Sea schematized as network of channels. In addition, some trial calculations were performed ue a method of integration by power series. It was not necessary to base this latter calculation on a permanent condition so that, in addition to the for due to friction and hydraulic gradient, the momentum could also betaken int account. The calculation was, however, very cumbersome and could only be ar plied to a very much simplified network of channels. It was used to make cc rections to the results of the stationary calculation. In general, the resi of the non-stationary calculation were higher than those of the stationary, especially near the inlets.

After the storm surge disaster of 1953, the "Delta Commission" was set up, which in 1955 had to construct the frequency lines for the storm flood surges along the Dutch coast. These frequency lines had to show wat water level was attained with a certain frequency at all points along the coast. The aim of this was to be able to design a height for a sea-defence which 


\section{COASTAL ENGINEERING}

would guarantee a degree of safety suited to the value of the area lying hind. For this, the frequency lines of the observation stations in the $\|$ Sea had also to be used. Because the period of observation since the enc ure of the Zuider Sea amounted to only 23 years and was therefore too sh for estimating very infrequent levels, the data from before 1932 had to treated in such a way that it fitted into the frequency lines found afte closure.

At the same time, it was possible to use this research to test the diction of the S.C.I. against actual conditions. Until then this had only done approximately for individual storms.

For the frequency lines, all storms from before the enclosure had $t$ considered; it was not sufficient to calculate the rise for a few chosen storms.

The following methods were used for this:

1. STATISTICAL METHOD。

For each storm, the North Sea level "W" is derived from observation coastal stations which lie sufficiently far from the region influenced b enclosure. This derived North Sea level is therefore independent of the closure of the Zuider Sea.

The difference between $N$ and the observed storm surge level at a ce station is plotted graphically against $N$. Two lines are then drawn; one through the points representing storms before the enclosure and one thro points from after the enclosure. The ordinate between these two lines $g i$ the rise in storm surge level at a certain station as a function of the surge level in the North Sea outside the inlets.

In this fashion, all observations from before the enclosure can be verted to the situation after enclosure.

\section{LINES OF RELATIONSHIP.}

In this method each of the stations influenced by the enclosure is pared with a station not subject to such influence. The storm surge leve the two stations are plotted graphically, one against the other. As befo lines are drawn through points which represent levels before and after e closure. The ordinate between the two lines gives the rise at a certain ion as a function of the storm surge level at the other station. A Wadde station can of course be compared with more than one uninfluenced statio

Both methods have rather serious disadvantages. One of the most ser is that in this analysis, the duration of the storm is neglected and it this duration which is so important in connection with the filling of th Zuider Sea. At a station in the neighbourhood of the enclosing dam a pro ed storm before the enclosure can lead to the same water levels as a sho storm after the enclosure. In the analysis described above, no rise in $s$ level would be noticed.

The points in the graphs therefore show a rather large scatter. It only the more or less uniform behaviour of the storms which prevents the scatter from being even greater. Fig 5 has been appended as an example 0 such a graph. In it, the rise in storm surge level for Den Dever has bee determined by the statistical method. 


\section{COASTAL ENGINEERING}

lets and the system of channels behind, and this would continue until a $r$ equilibrium was reached. The delay in response of the Wadden need not be same at every point. There are reasons for believing that the build up ix region of the inlets takes precedence over that further back in the Wadc Sea. Material which is brought in through the inlet will settle out in tl direct neighbourhood rather than further back. Furthermore, the wave move further back in the Wadden Sea is stronger than in the lee of the islands The height of the Wadden with respect to H.W. therefore decreases landwar from the inlet.

The bed of the Wadden Sea consists chiefly of fine sand. Silt hardly settles out at all; the Wadden are too exposed to the action of wind wares for this to occur. Only in sheltered corners and with artificial means, s as the reclamation works along the Frisian and Groningen coast, can the : settle out. Also the digestive processes of shell-fish cause some silt tc settle.

All sediments have their origin in the North Sea, as has been shown petrographic research. River sand or river silt is not found. Silt can al originate in clay layers in the Wadden Sea itself which become exposed anc eroded through the morement of channels.

The material for building up the bed must therefore come into the W: Sea through the inlets. It may come from littoral drift, by erosion of th North Sea coast and perhaps also directly from the bed of the North Sea. littoral drift alone is, according to van Bendegom (litt. 2), insufficier satisfy the sand hunger of the Wadden Sea.

During the last 50 years the relative rise in sea level amounted to $2 \mathrm{~mm}$ per year. For an area of $1500 \mathrm{~km}^{2}$, the amount of sand required is $3 \times 10^{6} \mathrm{~m}^{3}$ per year.

The stretch of coast on the North Sea which is influenced by the Was Sea loses, owing to erosion, an amount of sand roughly estimated at about $1 \times 10^{6} \mathrm{~m} 3$ per year. The amount of material which enters the Wadden Sea 1 the inlets is unknown, With the present day instruments and measurement 1 niques, it has proved impossible to measure a resultant sand- and silt-t] port with sufficient accuracy。

The amount of silt which arrives by 6 discharge from the IJssel Lake: relatively insignificant, about $0.5 \times 10^{6} \mathrm{~m}^{3}$ per year.

The enclosure of the Zuider Sea has had a big influence on the proce described above. As a result of enclosure, over almost the whole of the 1 Wadden Sea (as far as the Terschelling watershed), high water level has $]$ from $0,1-0,3 \mathrm{~m}$. This has the same effect as a sudden rise of a similar in the sea level. The sand hunger of the Wadden Sea has increased strong: a result.

Since the enclosure, bed-levels have been regularly sounded, especi, in a strip $10 \mathrm{~km}$ wide along the enclosing dam.

A calculation of the difference in bed-level for this area over the period since enclosure, shows that, after correcting for the rise in sea level, an average of $9-10 \times 10^{6} \mathrm{~m}^{3}$ per year of sand and silt is laid du this is equivalent to $2 \mathrm{~cm}$ per year. The greater part of this material hi been deposited in the channels which have been blocked by the enclosing ( 


\section{THE NATURAL DEVELOPMENT OF THE WADDEN SEA AFTER THE ENCLOSURE OF THE ZUIDER SEA}

(7 - $8 \times 10^{6} \mathrm{~m}^{3}$ per year). The sand flats, in so far as they are found in this area, have even become lower - about $1 \mathrm{~cm}$ per year. It must however be noted that a great proportion of the flats considered lie in the region of the Dove Balg, where the movement of water has increased considerably since the enclosure. The enlargement of the cross-sectional area available for f] may perhaps be sought outside the limits of the Dove Balg and extending ove the flats on either side.

There is also a possibility that material is disturbed by wave action and transported to the dead-end channels where it settles out and is thus taken out of circulation.

Since enclosure the transport of sand and silt to the $10 \mathrm{~km}$ strip con. sidered has been greater than that which would correspond with the rise in sea level. Actually, it is even greater than would be necessary to keep up with the rise in sea level over the whole Wadden Sea. The origin of the ma. terial is not clear. It may be partly derived from the rest of the Wadden: but a large part must have come from the North Sea.

An approximate survey of the height of the flats behind Texel and Vlid land has shown that since the enclosure, these flats are becoming lower by an average of $2-3 \mathrm{~mm}$ per year. From this, a quantity of sand would be re. leased of about $0,5 \times 106 \mathrm{~m} / 3$ per year. If the other flats in this area beh. similarly, then about $10^{6} \mathrm{~m}^{3}$ of sand per year can be taken up.

An attempt to establish a sand and silt balance for the western Wadde Sea gives the following result:

Settling in the strip c. $10 \mathrm{~km}$ wide, north of enclosing dam

Taken up from the flats to the

north of this area

$10 \times 10^{6} \mathrm{~m}^{3} /$ year

Transport along the North Sea coast, according to van Veen 6 ( 1 itt.8)

amounts to $1-2 \times 10^{6}$ per year.

If almost all of this enters the

Wadden Sea, then we have

Coastal erosion can supply a

maximum of

From erosion of the external deltas, maximum

IJssel Lake silt

Directly from the North Sea, errors in

the above estimates and unknown sources

$1 \times 10^{6} \mathrm{~m}^{3} /$ year

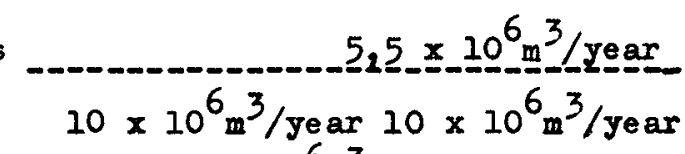

$10 \times 10^{6} \mathrm{~m}^{3} /$ year $10 \times 10^{6} \mathrm{~m}^{3} /$ year

From the above data and assumptions, about $8 \times 10^{6} \mathrm{~m}^{3} /$ year enters the western Wadden Sea through the inlets. The capacity of the inlets of Den Helder and the vile together amount to $2 \times 10^{9} \mathrm{~m}^{3}$. If it is assumed that half of the transport takes place over the bed and the other half in suspe ion, then a difference in concentration of $4-5 \mathrm{mg} / 1$ would be sufficient carry $4 \times 10^{6} \mathrm{~m} /$ year of suspended solids into the Wadden Sea. As the aver content is $40 \mathrm{mg} / 1$, the accuracy of measurement would have to be better th $10 \%$ to be able to show this resultant transport. Bed transport measuremen are even less accurate than measurements of transport in suspension. The c clusion is therefore that in the western Wadden Sea a large amount of mate is deposited, the origin of more than half of which is unknown. Measuremen of transport in the inlets cannot provide any information because of the $r$ 


\section{COASTAL ENGINEERING}

\section{Table 2}

Hydrographical data of Wadden Sea

\begin{tabular}{|c|c|c|c|c|c|c|c|c|c|c|c|c|c|}
\hline \multirow[b]{2}{*}{$n x ;$} & \multirow{2}{*}{$\begin{array}{r}\text {-tation } \\
\text { name }\end{array}$} & \multicolumn{6}{|c|}{ mean tidal condition } & \multirow{2}{*}{$\begin{array}{l}\text { area of } \\
\text { crooes } \\
\text { sootion } \\
\text { in } \approx^{2}\end{array}$} & \multirow{2}{*}{$\begin{array}{c}c \\
m^{2} / e 0 c\end{array}$} & \multirow{2}{*}{$\begin{array}{l}\tau_{\max } \\
N / m^{2}\end{array}$} & \multirow{2}{*}{$\begin{array}{l}u_{* \max } \\
=/ \sec \end{array}$} & \multirow{2}{*}{$\begin{array}{c}\text { bed } \\
\text { material } \\
\text { 1) }\end{array}$} & \multirow{2}{*}{$\begin{array}{l}\text { derelop- } \\
\text { ment of } \\
\text { cross- } \\
\text { section } \\
2 \text { ) }\end{array}$} \\
\hline & & $\begin{array}{l}\max , v e \text { ? } \\
\text { in } \mathrm{m} / \mathrm{c} \\
\text { flood }\end{array}$ & ${ }^{\bullet}{ }_{a b b}$ & $\begin{array}{l}\max , d 1 a c \\
\text { in } 10 \\
n \text { nood }\end{array}$ & 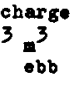 & $\begin{array}{l}\text { tidal p } \\
\text { in } 10^{6} \\
\text { flood }\end{array}$ & : & & & & & & \\
\hline & 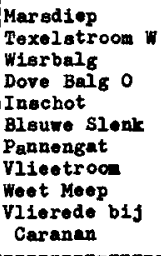 & $\begin{array}{l}1,8 \\
1,4 \\
0,8 \\
1,2 \\
0,8 \\
1,0 \\
1,3 \\
1,6 \\
1,3\end{array}$ & $\begin{array}{l}1,6 \\
1,4 \\
0,6 \\
0,8 \\
1,0 \\
0,9 \\
0,2 \\
1,1 \\
1,1 \\
1,1\end{array}$ & $\begin{array}{r}72,0 \\
46,0 \\
16,0 \\
16,0 \\
8,4 \\
8,2 \\
7,0 \\
31,5 \\
21,0\end{array}$ & $\begin{array}{r}64,0 \\
43,0 \\
-10,8 \\
7,0 \\
5,9 \\
7,5 \\
25,5 \\
22,0 \\
-\end{array}$ & $\begin{array}{l}930 \\
615 \\
-170 \\
120 \\
130 \\
115 \\
475 \\
350 \\
-\end{array}$ & $\begin{array}{l}1020 \\
710 \\
170 \\
125 \\
100 \\
135 \\
425 \\
375\end{array}$ & $\begin{array}{l}54.000 \\
44.500 \\
3.200 \\
15.200 \\
10.700 \\
9.000 \\
8.000 \\
25.000 \\
18.500 \\
40.000\end{array}$ & $\begin{array}{l}53 \\
53 \\
50 \\
50 \\
50 \\
50 \\
50 \\
52 \\
52 \\
53\end{array}$ & $\begin{array}{l}6,4 \\
3,8 \\
3,9 \\
4,4 \\
2,5 \\
3,3 \\
3,5 \\
5,9 \\
5,2 \\
6,0\end{array}$ & $\begin{array}{l}0,08 \\
0,06 \\
0,05 \\
0,06 \\
0,05 \\
0,06 \\
0,06 \\
0,07 \\
0,07 \\
0,08\end{array}$ & $\begin{array}{ll}I I, & \text { II } \\
\text { II, III } \\
I I, & \text { III } \\
I I & \\
I I, & I I \\
I & I I \\
I & I I \\
I I & \\
I & \end{array}$ & $\begin{array}{l}1,04 \\
0,88 \\
0,48 \\
1,26 \\
0,67 \\
1,16 \\
1,1 \\
1,28 \\
1,20\end{array}$ \\
\hline & & & & & & $\begin{array}{l}\text { and, } \\
\text { ve }\end{array}$ & & & $\begin{array}{l}\text { ilt } \\
\frac{61 \text { th }}{60}\end{array}$ & & & & \\
\hline
\end{tabular}

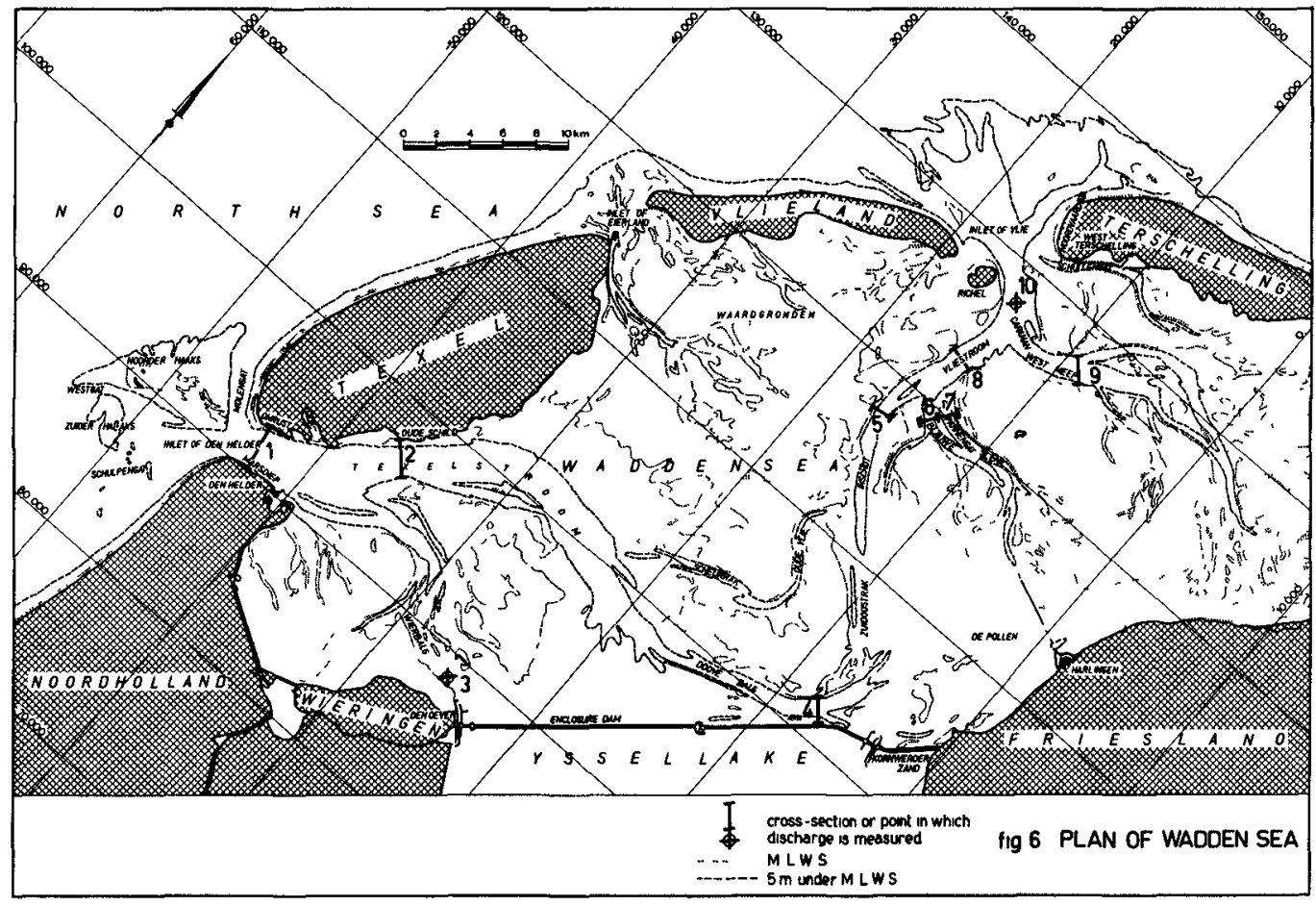

Fig. 6. Plan of Wadden Sea. 


\section{THE NATURAL DEVELOPMENT OF THE WADDEN SEA AFTER THE ENCLOSURE OF THE ZUIDER SEA}

quired accuracy of measurement. The only arailable method appears to be $t$. establishment of sand and silt belances over long periods using soundings. beach measurements over the whole area which is influenced.

\section{Special considerations (see fig 6).}

The systems of channels running from the Inlet of Den Helder and the let of Vlie meet each other in an extensive area of zero horizontal tide the neighbourhood of Harlingen. Formerly, both systems ran approximately: rallel to the Zuider Sea. A resultant water transport from the Inlet of $D_{i}$ Helder to the Inlet of Vile hardly occurs. For both inlets, the volume of $e b b$ is almost equal to that of the flood.

The connections between the two channel-systems originated in the ph lag between the tide in the inlets of Den Helder and Viie.

After the enclosure, two connections remained north of the enclosing namely the Dove Balg and the Scheurrak - Oude Vlie channel.

The tide comming from the Inlet of Den Helder is 80 much earlier tha that coming from the Inlet of Vile that both connections are entirely und the influence of the former inlet. The flood in the Scheurrak meets that the VIie near the confluence of the Oude VIie with the Inschot. Because 0 this, the flows in the former channel have somewhat decreased.

The Dove Balg however, at present, carries a large quantity of water the direction of Harlingen and the cross section of this channel has incr appreciably since enclosure.

This growth in cross section causes the tide on the east side to arr earlier, so that the area of influence is still increasing. Moreover, becal of this, the tidal $r$ ange in the area round Harlingen is still increasing slightly. From fig 3 it is seen that for Harlingen, after correction for influence of the inclination of the lunar orbit, there is an average incri in the tidal range of $3 \mathrm{~cm}$ in 20 years. Because of the growth of the Dove the tidal range at Oude Schild is decreasing, as also can be seen in fig. The earlier appearance of the tide at both stations is in agreement with

The channels to the north and east of Wieringen, which formerly carr: water to the Zuider Sea, now cater for the filling of only a small area $r$ Wieringen. Their dimensions are therefore rapidly diminishing. As a resul. this, the tidal range at Den Oever has somewhat decreased since the enclo (see fig 3).

The Texelstroom remains almost unchanged, except for the eastern par The discharge here has also varied little since the enclosure.

The Marsdiep, the throat of the Inlet of Den Helder, also hardly var: in cross section, although the max. discharge here has increased by about The southern shore has been stabilised and the depth is very great, in pl, $45 \mathrm{~m}$. The bed consists of coarse sand. It is not known why the cross sect: area remains practically constant.

The channels which are influenced by the Inlet of Vlie are, with the exception of the Inschot, becoming larger. This is a consequence of the is creased tidal movement in this area, which was predicted by the S.C.I.

The tide at Terschelling has been increasing rather rapidly since en- 


\section{COASTAL ENGINEERING}

closure (about $7 \mathrm{~cm}$ in 20 years). This would indicate an influence of the $f$ let between Terschelling and Ameland in which the tidal movement is strong; than in the Inlet of Vlie. Since enclosure, the tide at Terschelling arrive earlier. This is in contradiction to the assumption made above, The actual cause of the behaviour of the tide at Terschelling is unknown.

The Inschot has not grown because the discharge here has not increases as a result of the watershed which has formed near by.

An interesting area is the Pollen, This is a basin with an almost horj zontal bed with several very shallow channels. The explanation of the origi of this area (where actually a rather high flat might have been expected) I possibly as follows. The area was formed by erosion of the upper peat layej and/or by transgression. The supply of material from the North Sea was not sufficient to keep up wich the rise in sea level over the whole of the Wads Sea and the flats in the neighbourhood of the inlets received the greater I of the material. The shortage was felt chiefly in the area lying farthest landwards, that is the Pollen. The build up of the bed or formation of flat therefore lags far behind the increase in sea level. In addition, wave atta can be playing a part. With $S W$ to $N$ winds (the direction of gales) the are: lies the farthest behind the sheltering row of islands so that the waves hes are high. line sediment (other sediment never settles in this area) is thes fore easily brought into suspension and is then carried further by the curs This process does not occur exclusively at times of storm surges, because 1 bed is at $2-3 \mathrm{~m}$ below mean sea level and is soon disturbed by the movemer of waves.

In general, the behaviour of the channels corresponds quite clearly tc the movement of the water. In table 2 the results of flow measurements in : number of channels are presented. The lines along which discharge is measus are shown in fig 6. The measurements were performed in 1957 - 1959. By mear of this data and from measurements of hydraulic gradient, several factors 1 been calculated such as Chézy's coefficient $c$, the bed shear stress $\tau$ max'
the shear-velocity $u_{*}$ max. These last two factors were calculated using following formulae:

$$
\begin{array}{ll}
\tau=\rho g \frac{\varphi^{2}}{A^{2} c^{2}} & \text { Newtons } / \mathrm{m}^{2} \\
u_{*}=\frac{\sqrt{g}}{c} \cdot \frac{\varphi}{A} & \mathrm{~m} / \mathrm{sec}
\end{array}
$$

where $C=$ Chezy's coefficient in $\mathrm{m}^{\frac{1}{2}} / \mathrm{sec}$

$A=$ cross sectional area in $\mathrm{m}^{2}$

$\tau=$ bed shear stress in Newtons $/ \mathrm{m}^{2}$

$p=$ density of water in $\mathrm{kg} / \mathrm{m}^{3}$

$g=$ acceleration due to 3 gravity in $\mathrm{m} / \mathrm{sec}^{2}$

$Q=$ max. discharge in $\mathrm{m}^{3} / \mathrm{sec}$

$u_{*}=$ shear velocity in $\mathrm{m} / \mathrm{sec}$

Further, at the end of the table, the type of bed material and the behaviou of the cross sectional area are described.

The influence of the external deltas.

The existence of an external delta at an inlet which is subject to strong tidal movement, is a common phenomenon. The external delta provides bridge for the littoral drift across the perpendicular flow in the inlet. I the transport takes place in the form of banks which erode on one side and accrete on the other and transplant themselves in their entirety across the 


\section{THE NATURAL DEVELOPMENT OF THE WADDEN SEA AFTER THE ENCLOSURE OF THE ZUIDER SEA}

external delta. A cyclic process of this type can be observed in the delte the Inlet of Den Helder. However, the Noorder Haaks is here exeptional. Th is presumably a very resistant bank which maintains almost the same positj The banks moving up from the south unite with the Noorder Haaks and from 1 a flat makes the crossing of the northern channel of the delta and joins $j$ self to the island of Texel.

To the south of the Noorder Haaks lie two channels: Schulpengat and Westgat. At the moment, the Westgat is being pushed against the Noorder Hz by the Zuider Haaks and is sanding up. The Schulpengat is therefore beginr to take over the function of the Westgat and a new Schulpengat is being $f c$ along the coast of North Holland.

To the north of the Noorder Haaks lies one channel, the Molengat. Thj too is moving from south to north, under influence of the pressure of the bank which is moving from the Noorder Haaks to Texel. A former Molengat ce be discerned in the Mok on Texel. The Onrust is a bank which has crossed c This course of events was shown by Ir.Grijm at the congress in Schereninge in a film which was made by means of successive sounding charts.

The derelopment of the Inlet of Vlie is much less clear. If it exists cycle here apparently takes much longer to complete.

However, the pressure of the eastern part of Vlieland is quite eviden Because of this pressure, the inlet is being driven eastwards.

The western end of Terschelling, the "Noordvaarder", is a flat which united with Terschelling in about the 17th century. Old publications menti a navigable channel which connected with the North Sea directly to the wea of the harbour of Terschelling.

The swinging of the channels in the external delta influences the ori ation of the channels on the inside of the inlet. The transport of sand is probably not the same during the various phases of the development.

The Bierlandse gat, between Texel and VIieland experiences a similar course of events as the Inlet of Den Helder. Here there is only one main channel.

The cross-section of this inlet is increasing quite rapidly, probably a result of the shortage of sand in the external delta and a relatively sm littoral drift.

The development has apparentIy been influenced by the enclosure of th Zuider Sea. From 1911 to 1930 , the cross sectional area,oscillated about a value of $10.000 \mathrm{~m}^{2}$; after 1930 it increased to $15.500 \mathrm{~m}^{2}$ in 1960.

\section{Future development.}

The most important factors here are:

- the relative rise in sea level

- the transport of sand to the Wadden Sea

- coastal engineering

There is little known about the future morement of the sea level. Thi is dependent upon the climate on the earth and upon many other factors whe by the ratio of water to ice is altered. Observations over the whole earth indicate both rising and falling sea levels. 


\section{COASTAL ENGINEERING}

However, seeing that an important part of the relative rise in sea le is caused by consolidation of sediments and subsidence of the earth, it ca be assumed that the present movement will continue for the next few centur although perhaps at a different rate.

The amount of sand arriving will decrease because the Dutch and Belgi coasts are being increasingly protected against erosion by means of groyne In some places, harbour piers are being built far out into the sea (IJmuid Europoort) whereby the littoral drift is interrupted,at least for some tim

As long as the North Sea does not become shallower, no increased tran port of material from the sea bottom is to be expected.

The expectation is therefore that, if the present rise in sea level $c$ tinues, the Wadden Sea as a whole will undergo little change. Owing to the shortage of sand, it is possible that the delay in response of the Wadden increase. The relative lowering and diminution of the flats which will acc pany this, can cause an increase in the capacity of inlets.

Local changes will continue to occur, especially in the area which is fluenced by the enclosing dam.

It is conceivable that in the distant future all the Wadden or a lare part of it will disappear and a region will be created similar to the pres day Pollen.

There are various reasons for wanting to terminate the existence of $t$ Wadden Sea.

By closing the inlets, the coast line would be appreciably shortened, This would yield greater safety as well as economic advantages. The closus is technically possible especially now that in the Rhine delta so much ed perience will be gained in large closures.

The removal of the sand hunger of the Wadden Sea would cause the coas erosion along the North Sea to decrease. The external deltas would disappe and a clear coast would arise such as that of North and South Holland. Bec of this, it is possible that the heads of the Wadden islands, which now p3 into the sea because they are sheltered behind the external deltas, would attacked and serious local erosion would occur.

Owing to the build up of the bed, the clay and peat layers of the Ho: cene which still exist will be buried to increasing depths under new sea: If it is the intention to use the Wadden for agricultural purposes in the future, the closure of the inlets must not be delayed for too long.

A study of the soils in 1950 - 1952 showed that by meang of deep plo on the flats between Den Helder and Wieringen, $64 \%$ or $50 \mathrm{~km}^{2}$ of clayey s: heavier soil can be reclaimed and on the flats behind Texel and vileland: or $120 \mathrm{~km}^{2}$. If the sand were to continue covering the flats, these areas; decrease.

At the moment there are no concrete plans for large civil works in tl western Wadden Sea. Activity is temporarily diverted to the south, to the urgent closures in the Rhine delta.

The future will doubtless see the closure of the inlets of the Waddes Sea. This closure may be partial and may or may not be accompanied by wos 


\section{THE NATURAL DEVELOPMENT OF THE WADDEN SEA AFTER THE ENCLOSURE OF THE ZUIDER SEA}

of reclamation.

\section{REFERENCES}

1. Staatscommissie Zuiderzee (1918 - 1926). Report of the State Commission for the Zuider Sea. Algemene Landsdrukkerij. The Hague, 1926

2. Various authors (1950). Waddensymposium. Reprint from the Tijdschrift Koninklijk Nederlandsch Aardrijkskundig Genootschap. May 1950。

3. Postma, H. (1954). Hydrography of the Dutch Wadden Sea (thesis).

4. Wemelsfelder, P.J. (1960). On the use of frequency curves of stormflood Proceedings 7 th Conference Coastal Engineering, The Hague, Netherl Aug. 1960.

5. Wiggers, A.J. (1952). De bodemgesteldheid van het westelijke Waddengebj Rapport van de Directie van de Wieringermeer - Landbouwkundige afd (The nature of the bed in the western Wadden Sea. Report of the BC of the Wieringermeer - Agricultural Department).

6. Vlam, A,W. (1936). Resultaten van een onderzoek naar de kaarten van het zeegat van het Vlie van de 16 eeuw tot 1800. (Results of researob to the maps of the Inlet of vile from the 16th century until 1800) Tijdschrift Koninklijk Nederlandsch Aardrijkskundig Genootschap, J pp. $202-209$.

7. Burght, J.H.van der (1936). Veranderingen in de zeebodem van het zeegat het Vlie en in de kustlijn der Waddeneilanden Vlieland en Terschej ling. (Changes in the sea bed of the Inlet of Vlie and in the coas line of the Wadden islands, Vlieland and Terschelling). Tijdschrif Koninklijk Nederlandsch Aardrijkskundig Genootschap, 1936, Volume Pp. 212-237.

8. Veen, J, van (1936). Onderzoekingen in de Hoofden in verband met de gest heid van de Nederlandsche kust. (Research in the English Channel i connection with the condition of the Dutch coast), The Hague, Alge mene Landsdrukkerij.

9. Bruun, P. and Gerritsen, F. (1960). Stability of Coastal Inlets. North Holland Publishing Company, Amsterdam.

10. Dillo, H.G. (1960). Sandwanderung in Tideflüssen. Mitteilungen des Fran Instituta für Grund- und Wasserbau der TechnischeHochschule, Heft Hannover. ( The movement of sand in tidal atreams. Report of the Franzius Institute for Civil Engineering of the Technical Universi of Hannover, Volume 17).

11. Horst, H. (1960). Die Geschwindigkeitsverteilung in offenen Gerinnen be turbulenter Strömung und ihre Beziehungen zum Geschiebetransport. Deutsche Gewässerkundliche Mitteilungen, Jahrgang 4, Heft 3 und 6. (Velocity distribution in open channels with turbulent flow and it effect on the bed load). 